\title{
Effects of different factors influencing the essential oil properties of Thymus vulgaris $\mathrm{L}$.
}

\author{
Zsuzsanna Pluhár*, Dóra Szabó and Szilvia Sárosi \\ Department of Medicinal and Aromatic Plants, Faculty of Horticultural Sciences, Szent István University, \\ Villányi út 29-43., Budapest, 1118, Hungary
}

\author{
Article history \\ Received: 2 June 2016 \\ Accepted: 11 August 2016 \\ Published: 18 September 2016 \\ (C) Pluhár et al. (2016) \\ Special Section \\ Target constituents in medicinal, \\ aromatic and food plants \\ Section Editor \\ Alessandra Bertoli \\ Publisher \\ Horizon e-Publishing Group \\ Corresponding Author \\ Zsuzsanna Pluhár \\ \. pluhar.Zsuzsanna@kertk.szie.hu
}

\begin{abstract}
Thymus vulgaris $\mathrm{L}$. is a well-know medicinal and aromatic plant native to the Mediterranean region. The essential oil is considered as the main active constituent, being responsible for its typical odour and taste as well as for several therapeutic effects. Our aim was to demonstrate the most important factors influencing the quality and quantity parameters of thyme oil by summarizing the available literature data and our own scientific results. Genetic background, climatic and growing conditions, techniques of primary processing, storage conditions as well as different extraction methods have proven effects on the essential oil properties and, as a consequence, on its biological activity, either.
\end{abstract}

\section{Keywords}

phenolic monoterpenes; genetic factors; environmental conditions; cultivation; processing technologies; extraction methods

Pluhár, Z., D. Szabó and S. Sárosi. 2016. Effects of different factors influencing the essential oil properties of Thymus vulgaris L. Plant Science Today 3(3): 312-326. http://dx.doi.org/10.14719/pst.2016.3.3.241

\section{Introduction}

Thymus vulgaris $\mathrm{L}$. is native to the WestMediterranean region and belongs to the Lamiaceae plant family (Heeger, 1989). Its medicinal properties have already been discovered by the ancient Egyptians (Zarzuelo \& Crespo, 2002). In the European folk medicine it is used against skin inflammations, ulcers, rheumatic complaints and neuralgia (Schaunberg \& Paris, 1977; Furlenmeimer, 1984). Applied internally almost all of its therapeutic effects are in connection with the respiratory system, since it is a good expectorant having antispasmodic and antiseptic effects as well (Bardeau, 1973; Poletti, 1979). Garden thyme can also be used against problems of the digestive system; it is useful in the cases of flatulence and gastric ulcer, too (Perrot \& Paris, 1971; Furlenmeier, 1984).
Owing to its essential oil content it has a pleasant odour and taste; therefore it is used worldwide as a spice for culinary purposes.

\section{Essential oil properties and utilization}

Thymi herba (dried, crumbled leaves and flowers) and Thymi aetheroleum (hydrodistilled essential oil) - are official drugs listed in the European Pharmacopoeia (Ph. Eur. 7.0, 2010). Dried aerial parts of Thymus vulgaris L. and/or T. zygis L. can be used as raw materials for primary processing of the drugs. According to the pharmacopoeal specifications, Thymi herba contains at least 12 $\mathrm{ml} / \mathrm{kg}$ essential oil, calculated on the dry weight (DW) basis, where the relative percentage of the phenolic monoterpene constituents (thymol and carvacrol) is required to to reach $40 \%$. 
The essential oil is still considered as one of the most important active agents of Thymus species, having great importance from medicinal and food industrial point of views as well. Gildemeister and Hoffmann described the composition of garden thyme essential oil at first in 1961. Between 1960 and 1989 several experiments were carried out concerning quantity and quality parameters of thyme essential oil by examining the influence of biotic and abiotic factors on the essential oil properties (StahlBiskup, 1991).

In thyme essential oil, the ratio of monoterpenes is generally high, up to $90 \%$; until nowadays almost 270 essential oil components have been identified in it. The main compounds thymol and carvacrol - have phenolic characteristics (Stahl-Biskup, 2002).

The possible therapeutic effects of the essential oil and its main compounds have also been analyzed. According to the literature data, the phenolic compounds have strong antibacterial and antifungal effect showing good efficiency against Candida sp. (Osawa et al., 1990; Panizzi et al., 1993; Zambonelli, 1996; Sacchetti et al., 2005; Braga et al., 2010); their anti-inflammatory (Fachini-Queiroz, 2012), insecticidal (Szczepanic et al., 2012) and antispasmodic (Begrow et al., 2010) effects have also been described. The strong antioxidant effect of the whole essential oil and its main compounds - thymol and carvacrol - has been analysed several times, the main results are summarized in Table 1. Because of the established strong antibacterial, antifungal and antioxidant effect of the essential oil it can also be used as a natural food preservative (Nowak et al., 2012).

Not only the main essential oil compounds were tested; also geraniol, borneol, carvacrol methyl ether, sabinene, ocimene, linalool, $\alpha$ terpinene, $\alpha$-pinene, $\quad p$-cymene, $\beta$-pinene, $\alpha$ humulene, limonene, $\gamma$-terpinene, trans- $\beta$ caryophyllene, terpinen-4-ol, $\delta$-3-carene, 1,8 cineole and myrcene were found to have antioxidant properties ranking on their relative antioxidant capacity in the given order (Deans et al., 1993; Dorman et al., 2000). In the research work of Ruberto and Baratta (2000) 98 pure essential oil compounds were tested as potential free radical scavengers or lipid-peroxidation inhibitors, among them several can be found in the essential oil of garden thyme. The authors emphasized that, besides thymol and carvacrol, in particular $\alpha$ - and $\gamma$-terpinene also had a comparable activity to that of $\alpha$-tocopherol, used as reference. From this point of view, sesquiterpenes have significantly lower antioxidant activity. These compounds ( $\beta$-caryophyllene, a-humulene) have rather different effect; many literature data are referring to $\beta$-caryophyllene, concerning its potential anti-inflammatory (Fernandes et al., 2007; Horváth et al., 2012), antispasmodic (Leonhardt et al., 2010), and anxiolytic-like effects
(Moreira-Galdino et al., 2012). The antiinflammatory effect of a-humulene was also investigated (Fernandes et al., 2007). With relevance to other sesquiterpene compounds of garden thyme essential oil - $\delta$-cadinene, spathulenol, $\gamma$-muurolene - individual activity has not been investigated yet, however, several literature data are available referring to essential oils, rich in these sesquiterpenes, showing antifungal (Cakir et al., 2005), insecticidal (García et al., 2007) and anti-inflammatory effects (Tung et al., 2008).

Summarizing the literature data, the essential oil composition of garden thyme may influence significantly its possible therapeutic or food industrial applicability. Therefore, the main factors which can affect the quality parameters of the essential oil need to be investigated separately. Among them, the effects of the genetic background, climatic and growing conditions, way of drying and the different extraction methods will be discussed.

\section{The role of genetic factors on essential oil composition}

Thymus vulgaris L. (common/garden thyme) and $T$. zygis (Spanish thyme) belong to the Section VI. Thymus within the genus Thymus, which is classified into the tribe Menthae, subfamily Nepetoideae and family Lamiaceae (Morales, 2002).

The genus Thymus represents high infraspecific morphological variability and chemical polymorphism caused by environmental factors and genetic variation due to frequent hybridization and sexual dimorphism (gynodioecy) (Stahl-Biskup, 1991, 2002; Morales, 2002; Marin et al., 2003; Dajić-Stevanović et al., 2008). Taxonomically Thymus is a very complex genus, because of the polymorphism of a number of species and the absence of intrageneric incompatibility. Interspecific and introgressive hybridization between related species is a very common phenomenon and the main reason of variation. The resulting hybrids often have intermediate or mixed morphological characteristics (Hernández et al., 1987; Marin et al., 1996). However, the greatest biodiversity of Thymus was reported from the Iberian Peninsula and from Turkey (Salgeiro et al., 1997; Baser et al., 1996; Pérez-Sánchez et al., 2008).

Polychemism of the genus Thymus is a consequence of the dynamic evolution, not only preserving the species but also provides a territorial favour in the process of adaptation to the continuously changing environment. Essential oil chemotypes of thyme species can be considered as chemical races (Hegnauer, 1978) as their populations are geographical distinct with inheritable chemical properties (Stahl-Biskup, 2002). The studies on the polymorphism of the genus Thymus started with the publications of Granger and Passet (1971, 1973), who reported 6 
Table 1 Antioxidant activity of garden thyme essential oil according to the literature reviewed

\begin{tabular}{ll}
\hline Antioxidant activity & Literature data \\
\hline Protect against lipid peroxidation in vitro (essential oil) & Deans et al., 1993, Dorman et al., 1995 \\
Protect against lipid peroxidation in vitro (thymol, carvacrol & Ternes et al., 1995, Yanishlieva et al., 1999 \\
Protect against lipid peroxidation in vivo (essential oil) & Recsan et al., 1997 \\
Free radical scavenging activity (essential oil) & Mantle et al., 1998, Sacchetti et al., 2005 \\
Free radical scavenging activity (thymol, carvacrol) & Aeschbach et al., 1994, Dorman et al., 2000 \\
Enhancing the activity of superoxide dismutase & Youdim and Deans, 1999 \\
\hline
\end{tabular}

chemotypes for T. vulgaris after studying several populations and a great number of individuals in the south of France. Natural populations contain one or several of six genetically distinct chemical forms (chemotypes) that can be distinguished on the basis of the dominant monoterpene produced in the glandular trichomes on the surface of the leaves and calyces. Each of the six chemotypes, geraniol (G), a-terpineol (A), tr-sabinen hydrate or thujanol-4 (U), linalool (L), carvacrol (C) and thymol (T), is named after the dominant monoterpene in the essential oil of the plant. Each monoterpene is at the end of a branch in a common reaction chain that has a precursor, geranyl pyrophosphate. Having different molecular structure, the six monoterpene can be divided into two main groups: phenolic (thymol and carvacrol) and non-phenolic (the other four monoterpenes) ones. The presence of the dominant monoterpene in T. vulgaris is controlled by an epistatic series of five loci with the following sequence: GAULCT. The metabolic pathway leading to the two phenolic chemotypes is much longer than that of the non-phenolic ones (Vernet et al., 1986). Directions of biosynthetic pathways are probably controlled by a series of regulator proteins (coded at loci G, A, U, L, C) capable to cease the biosynthesis chain in a specific place (Thompson, 2002).

The main constituent of commercial thyme oil is predominantly thymol (together with carvacrol up to 70 percent). This chemotype is the most widespread in the natural habitats and possesses therapeutical relevance attributed to Thymus species. Other chemotypes of T. vulgaris are limited to specific areas and are of minor importance with distinct application. Besides thymol chemotype of $T$. zygis, others produce an essential oil with other dominant constituents (linalool, carvacrol, geraniol/geranyl acetate, 1,8cieneol/linalool, linalool/thymol or 1,8cineole/linalool/thymol) (Venskutonis, 2002).

In order to optimize quality and yield of $T$. vulgaris, a breeding programme was carried out on F1 hybrids obtained by crossing male sterile and male fertile clones in Switzerland by Carlen et al. (2010), based on the methods and previous results of Rey (1993) and Rey et al. (2004) on hybrid varieties of 'Varico 1' and 'Varico 2'. The most promising hybrid was named as 'Varico 3' and was then compared to five established cultivars originating from Germany ('Deutscher Winter'), France (3 hybrids of ITEIPMAI) and Switzerland ('Varico 2'). 'Varico 3' showed high morfological homogeneity, outstanding dry yields (3.86 t/ha) as well as superior essential oil content $(4.9 \mathrm{ml} / 100 \mathrm{~g} \mathrm{DW})$ and thymol ratio $(65 \%)$ in the crumbled herba to the other accessions involved, confirming again the advantage of hybrid breeding in the case of common thyme, as it was also emphasized by Pank and Krüger (2003).

Only a few data are available on the significance and utilization of the other essential oil chemotype of garden thyme. Three hybride cultivars ('Carvalia', 'Thymlia' and 'Linalia') and 37 clones belonging to different essential oil chemotypes were developped by the ITEIPMAI, which are cultivated by the growers in France (Anonym, 2008).

In our work, ten selected clones of garden thyme, propagated by softwood cuttings in the autumn of 2007, were studied (Pluhár et al., 2010). Their parent populations had been established by seeds, originating from seed exchange, in 2002. As a result of the several years' evaluation of these populations, we have found a considerable level of chemical polymorphism. Finally, ten accessions of high (2-4 ml/100g DW) essential oil producing ability were selected and classified into five chemotypes. Concerning the dominant monoterpene of the essential oil, clones TV2, TV17, TV135 and 'Deutscher Winter' (used as a control) represented the thymol ('T') chemotype, while no. TV121 and TV127 were involved in the linalool ('L') one. Clone TV143 was grouped into the -terpineol/ terpinyl acetate ('A') chemotype, while TV132 was the member of the carvacrol ('C') one. At clones TV 107 and TV 115, geraniol ('G') and geranyl acetate were shown to be the chief monoterpenes in the volatile oil (Fig 1). The selected clones produced fairly high levels of essential oil (mean: 2.32 $\mathrm{ml} / 100 \mathrm{~g}$, min. $1.54 \mathrm{ml} / 100 \mathrm{~g}$, max.: $3.70 \mathrm{ml} / 100 \mathrm{~g}$ ) in their second growing season (2009). The vegetative propagation method highly contributed to the quite homogenous essential oil composition within clones, as it has been proven by evaluating GC/MS data of individual samples.

In spite of their economic importance, there is not much information on the genetic relationship concerning Thymus species (Echeverrigaray et al., 2001; Sunar et al., 2009). However, molecular biological data may provide a 


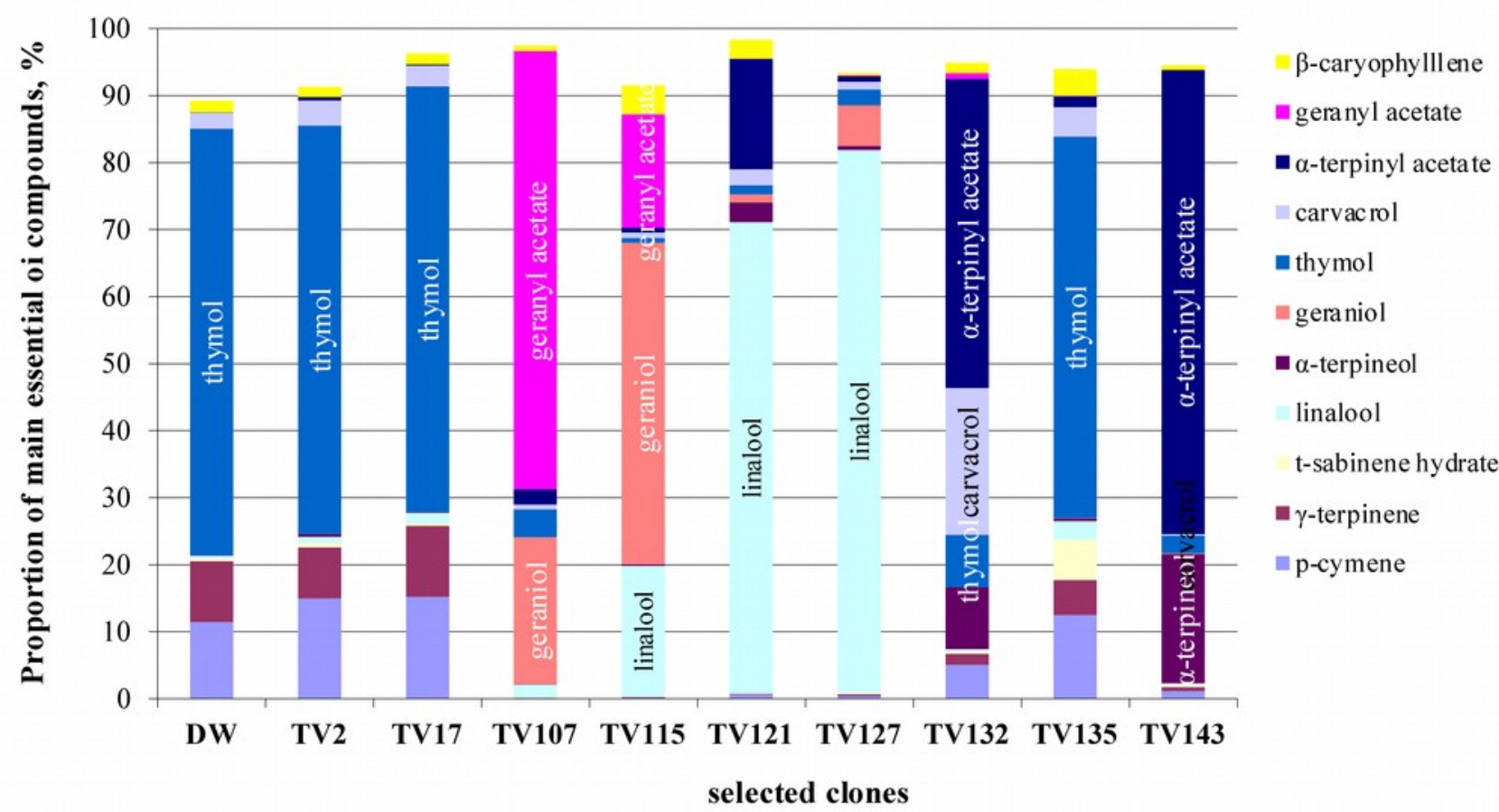

Fig 1. Essential oil composition of selected clones of different chemotypes belonging to Thymus vulgaris $\mathrm{L}$. (Budapest, 2009) (after Pluhár et al., 2010)

solution to the taxonomic problems both in intraspecific level and among the thyme species. The use of DNA marker techniques was proven to be important in the case of polymorph species with limited reliable taxonomic characters (Karaca et al., 2008; Ince et al., 2009). Echeverrigaray et al. (2001) studied the essential oil composition and genetic variability of six commercial Thymus vulgaris cultivars. All of the cultivars exhibited characteristic RAPD patterns that allowed their identification, and they could be divided into two clusters, which coincided with the results obtained by essential oil patterns. On the contrary, in the case of Iberian Thymus species, Trindade et al. (2005) did not find close correlation between chemical and molecular (RAPD) assessments. Figueiredo et al. (2008) has also pronounced that a new approach is necessary in exploring other molecular methodologies in order to fully determine the influence of both environmental and genetic factors on volatile composition.

To investigate the biosynthetic pathway to oregano terpenes and its regulation, Crocoll et al. (2010) recently identified and characterized seven terpene syntheses, key enzymes of terpene byosynthesis. They demonstrated that monoterpene synthase activity is predominantly regulated on the level of transcription and that monoterpene phenolic thymol is derived from $\gamma$ terpinene, a product of a single monoterpene synthase. It was proven that the terpene synthase expression levels directly control the composition of the essential oil. These results will facilitate metabolic engineering and directed breeding of oregano or thyme cultivars with higher quantity of essential oil and improved oil composition.

\section{Climatic and growing conditions affecting essential oil composition}

Abiotic environmental factors (temperature, moisture, soil and climatic conditions, elevation, etc.) as well as biotic effects (human disturbance, herbivors, etc.) influence both essential oil and polyphenol production of Thymus species and chemical composition of coenopopulations in the course of time (Gouyon et al., 1986). It was established that phenolic essential oil compounds (thymol, cavacrol) and polyphenols (e.g. flavonoids) favoured warmer and drier climatic zones while other, non-phenolic substances usually accumulate in higher quantities in cooler and more humid areas. Although different chemotypes favoured certain abiotic conditions, sometimes the plants of a particular chemotype grow in habitats that are less advantageous to them (Sáez, 1998). In addition, different chemotypes of the same species can grow in the same habitat as well (Salgeiro et al., 1997). These concerns prove that chemotypes are only partially dependent on the environment and support a direct relation of essential oil and flavonoid patters with the genetic features of these plants (Hernández et al., 1987; Vila, 2002).

The effect of weather conditions on nonvolatile phenolic compounds and on total antioxidant capacity were proven by Sárosi and Bernáth (2008) in the case of T. vulgaris, where the warm, sunny and dry growing season was favourable.

The importance of choosing the appropriate harvesting period was emphasized by Hudaib et 
Table 2. Essential oil characteristics of Thymus vulgaris L. lines investigated, depending on the growing year and the time of harvest (Budapest, 2003-2004) (after Kamondy et al., 2005)

\begin{tabular}{|c|c|c|c|c|c|c|c|c|c|c|c|c|}
\hline \multirow{3}{*}{ Line } & \multicolumn{4}{|c|}{ Essential oil content (ml/100g DW) } & \multirow{3}{*}{$\begin{array}{l}\text { P 5\% } \\
\text { growing } \\
\text { year, } 1^{\text {st }} \\
\text { cut }\end{array}$} & \multirow{3}{*}{$\begin{array}{c}\text { P 5\% } \\
\text { growing } \\
\text { year, } 2^{\text {nd }} \\
\text { cut }\end{array}$} & \multicolumn{4}{|c|}{ Thymol \% } & \multirow{3}{*}{$\begin{array}{l}\text { P 5\% } \\
\text { growing } \\
\text { year, } 1^{\text {st }} \\
\text { cut }\end{array}$} & \multirow{3}{*}{$\begin{array}{c}\text { P 5\% } \\
\text { growing } \\
\text { year, } 2^{\text {nd }} \\
\text { cut }\end{array}$} \\
\hline & \multicolumn{2}{|c|}{2003} & \multicolumn{2}{|c|}{2004} & & & \multicolumn{2}{|c|}{2003} & \multicolumn{2}{|c|}{2004} & & \\
\hline & $1^{\text {st }}$ cut & $2^{\text {nd }}$ cut & $1^{\text {st }}$ cut & $2^{\text {nd }}$ cut & & & $1^{\text {st }}$ cut & $2^{\text {nd }}$ cut & $1^{\text {st }}$ cut & $2^{\text {nd }}$ cut & & \\
\hline 2 & 1.246 & 1.096 & 1.280 & 1.057 & \multirow{6}{*}{0.792} & \multirow{6}{*}{0.608} & 55.05 & 37.47 & 59.18 & 46.54 & \multirow{6}{*}{0.143} & \multirow{6}{*}{$\underset{* *}{\mathbf{0 . 0 0 1}}$} \\
\hline 4 & 0.988 & 1.123 & 1.380 & 1.082 & & & 54.85 & 14.90 & 60.27 & 40.72 & & \\
\hline 11 & 1.119 & 0.757 & 1.087 & 0.874 & & & 53.33 & 37.90 & 64.92 & 35.20 & & \\
\hline 14 & 1.141 & 1.102 & 1.412 & 1.097 & & & 55.32 & 19.12 & 52.25 & 41.51 & & \\
\hline 17 & 1.331 & 0.945 & 0.415 & 1.429 & & & 52.32 & 32.92 & 54.15 & 39.35 & & \\
\hline 19 & 1.040 & 1.319 & 1.430 & 0.803 & & & 58.10 & 19.90 & 57.70 & 25.37 & & \\
\hline $\mathrm{p}_{5 \% \text { line }}$ & 0.139 & 0.236 & 0.664 & $0.032^{*}$ & & & 0.726 & 0.389 & 0.177 & 0.057 & & \\
\hline $\mathrm{p}_{5 \% \text { harvest }}$ & \multicolumn{2}{|c|}{0.057} & \multicolumn{2}{|c|}{0.003} & & & \multicolumn{2}{|c|}{$0.000 * *$} & \multicolumn{2}{|c|}{$0.000 * *$} & & \\
\hline
\end{tabular}

Legends for significance levels:* $\mathrm{p}<0.05^{* *} \mathrm{p}<0.01$

al. (2002), in order to achieve the highest quality and quantity of the essential oil, whose activity is known to be primarily correlated with the content of phenolic compounds.

In the study of Kamondy et al. (2005) on selected lines of $T$. vulgaris, the time of cutting (May and September) and the effect of growing year (2003-2004) were examined on the morphological, production biological and essential oil properties. Concerning essential oil content, there was no significant difference between the two years in the average of the lines: 1.179 (2003) and 1.185 (2004) ml/100 g were detected in Thymi herba in toto (uncrumbled, including stems), respectively. However, higher essential oil content and thymol ratio were detected at spring cutting $(1.329 \mathrm{ml} / 100 \mathrm{~g}$ and $57.06 \%)$ than at autumn harvest (1.035 ml/100 g and $32.44 \%$ ) (Table 2). Proportion of p-cymene has changed conversely: it was definitely higher in September (25.55 \%), then in May (12.84 \%). The quantity of the essential oil and the ratio of the compounds depended primarily on the time of cutting and possibly influenced by the pre-harvest wheather conditions as well. These results were in accordance with Hudaib et al. (2002). However, Jordán et al. (2006) pointed out that the most advantageous harvesting period for the Spanish wild populations of $T$. vulgaris, with 1,8-cineole as main compound, is in the mid-vegetative stage, when the maximum relative proportion of 1,8-cineole, borneol, camphor and monoterpenic hydrocarbons can be determined. In contrast, terpenyl acetate, aterpineol and linalool, associated with fresh aroma, were mostly concentrated from full bloom to advanced fruit formation.

The age of the thyme plantation has also affects the essential oil properties. Hudaib et al. (2002) have found that throughout the entire vegetation cycle, young (2-year-old) plants provided a markedly higher essential oil yield compared to the older (5-year-old) ones, with the highest thymol ratio as well.
Khazaie et al. (2008) studied the effect of irrigation ad planting density on the biomass and oil production of common thyme in a semi-arid region of Iran. Irrigation intervals did not change total biomass and oil production of thyme and higher values were shown in the second years of vegetation. The biomass of thyme plants was the lowest at the highest plant density.

Different doses of nitrogen fertilizers of thyme plantation had no significant effect on the essential oil content and composition in the experiment of Baranauskiené et al. (2003). However, the use of certain amounts of nitrogen fertilizers resulted in higher biomass production and, consequently, in elevated essential oil yields referring to unit area.

\section{The role of primary processing and storage on essential oil composition}

As it has already been mentioned, garden thyme is used as a spice world-wide owing to its characteristic odour and taste. Since in many countries fresh herbs for culinary purposes are rarely available on the markets, fresh plant material is usually preserved by drying; for this purpose convective drying is still the most popular method. However, several other preservation techniques can be applied, among them lyophilisation (freeze-drying) (Venskutonis, 1997), freezing (Usai et al., 2011), microwave drying (Deans et al., 1991) and solar-drying (Balladin \& Headley, 1999) have also been analyzed on garden thyme.

According to the recent results, the way of drying influences significantly the quantity and quality parameters of the essential oil in the final product (Venskutonis, 1997; Usai et al., 2011). Drying at low temperature (natural way of drying and artificial drying at $30^{\circ} \mathrm{C}$ ) can result in higher amount of essential oil (Raghavan et al., 1995), however too high temperature $\left(60-70^{\circ} \mathrm{C}\right)$ has negative effect on the quantity parameters (Venskutonis, 1997; Rahimmalek \& Goli, 2013). 


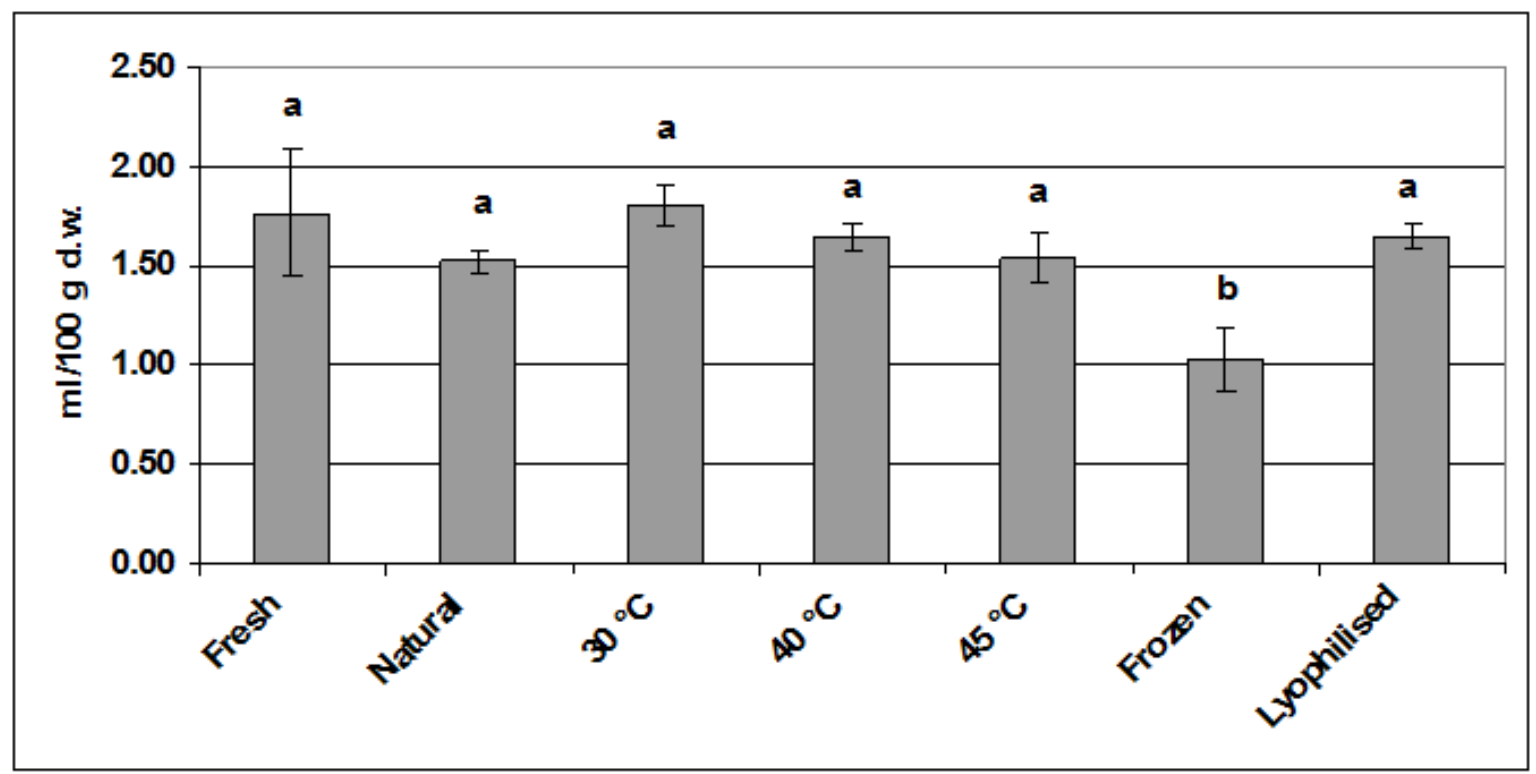

Fig 2. Effect of different drying-preservation methods on the essential oil content of garden thyme (Thymus vulgaris L.). Values signed by the same letters are not significantly different $(\mathrm{p}<0.05)$ according to Tukey’s multiple test.

Solar drying (wire basket drying method) and oven drying at $50^{\circ} \mathrm{C}$ were comparable to each other in the research work of Balladin and Headley (1999). Lyophilization is becoming more wide-spread also in the field of culinary herb preservation, for this reason its possible usage in the case of garden thyme has already been analyzed. The results are contradictory; according to Diaz-Maroto et al. (2002), freeze-drying can cause significant essential oil loss; on the contrary Venskutonis (1997) as well as Rahimmalek and Goli (2013) found higher essential oil amounts in the final product compared to other drying techniques (convective drying, sun-drying, microwave-drying). According to our results carried out in 2011 the way of drying did not influence significantly the essential oil content of garden thyme, only freezing had negative effect on it (Fig 2).

After the primary processing, the final products are usually stored for shorter or longer periods. In the case of garden thyme, for the best preservation of the quality parameters, storage temperature of $10^{\circ} \mathrm{C}$ is advisable. With increasing temperature, the declination of the essential oil content is more significant (Böttcher et al., 2001).

Similar to the essential oil content, the composition also changes during the primary processing. Even if at lower drying temperatures (natural way, and at $30^{\circ} \mathrm{C}$ ) we can preserve higher amounts of essential oil, the ratio of the valuable monoterpenes, among them thymol and carvacrol, decreases significantly, probably due to the longer drying process (Raghavan et al., 1995). Our results summarized in Table 3 are in accordance with these observations (Sárosi and Ruff, 2013). In the case of higher drying temperature it is obvious that the evaporation of the essential oil compounds will accelerate, that was affirmed by the findings of Venskutonis, 1997. In his research work drying at $60^{\circ} \mathrm{C}$ produced a huge loss of the total content of volatile constituents compared to the fresh, freeze-dried and $30^{\circ} \mathrm{C}$ dried samples. Referring to lyophilization, the literature data are contradictory, e.g. in the case of the essential oil amount. According to Venskutonis, (1997) freeze drying can preserve volatile compounds much more effective than other preservation techniques, while in the research work of Usai et al., 2011, freezing and air-drying produced better results. On the other hand, all authors agree that lyophilization is the best method to preserve thymol and carvacrol in higher ratios. Our own observations are in accordance with the previous findings of Venskutonis (1997) and Usai et al. (2011); the highest ratios of thymol were detected in the lyophilized samples (Table 3).

It is expected that not only the main compounds' ratios are affected by the drying methods. Percentage of 1,8-cineole was higher in the frozen and freeze-dried samples, than in the air dried samples; while in the case of $\beta$ caryophyllene the tendency was adverse (Usai et al., 2011). Similar results were shown by Venskutonis (1997): the amount of $\beta$-caryophyllene was higher in the lyophilized sample if compared to warm-air dried (at $30^{\circ} \mathrm{C}$ and $60^{\circ} \mathrm{C}$ ) materials.

The essential oil composition also changes during the storage, especially the loss of the valuable monoterpenes can be considerable (Venskutonis et al., 1996). In this field the only detailed research work was carried out by Usai et al. (2011); the air-dried and freeze-dried samples were characterized by the best results generally, where the retention of the volatile compounds was higher than in the frozen samples. However, in the frozen samples the ratio of thymol was higher by $42 \%$ compared to the fresh samples, while in the case of the air-dried and lyophilized samples a decrease of $19.69 \%$ and $8.80 \%$ was detected after 12 months of storage. 
Table 3. Effect of different drying-preservation techniques on the essential oil composition of garden thyme (after Sárosi et al., 2013)

\begin{tabular}{|c|c|c|c|c|c|c|c|c|c|}
\hline Component $^{\mathrm{a}}$ & RT & $\mathbf{L R I}^{\mathbf{b}}$ & Fresh & Natural & $30^{\circ} \mathrm{C}$ & $40^{\circ} \mathrm{C}$ & $50^{\circ} \mathrm{C}$ & Frozen & Lyophilized \\
\hline$\alpha$-thujene* & 5.31 & 928 & $0.06 \pm 0.07$ & $0.06 \pm 0.02$ & $0.20 \pm 0.01$ & $0.02 \pm 0.03$ & $0.02 \pm 0.03$ & $0.12 \pm 0.01$ & $0.06 \pm 0.12$ \\
\hline$a$-pinene & 5.56 & 938 & n.d. & $0.21 \pm 0.01$ & $0.35 \pm 0.01$ & $0.13 \pm 0.01$ & n.d. & n.d. & $0.24 \pm 0.48$ \\
\hline Camphene* & 5.95 & 952 & n.d. & $0.12 \pm 0.01$ & $0.20 \pm 0.00$ & $0.02 \pm 0.04$ & n.d. & n.d. & n.d. \\
\hline$\beta$-myrcene* & 6.99 & 995 & $0.29 \pm 0.06$ & $0.31 \pm 0.02$ & $0.19 \pm 0.01$ & $0.19 \pm 0.02$ & $0.04 \pm 0.09$ & $0.33 \pm 0.02$ & $0.07 \pm 0.08$ \\
\hline$\alpha$-terpinene $*$ & 7.79 & 1018 & $0.33 \pm 0.05$ & $0.57 \pm 0.02$ & $0.56 \pm 0.01$ & $0.50 \pm 0.01$ & $0.11 \pm 0.07$ & $0.47 \pm 0.02$ & $0.10 \pm 0.11$ \\
\hline$p$-cymene* & 8.09 & 1026 & $12.96 \pm 1.79$ & $18.39 \pm 0.69$ & $25.37 \pm 0.91$ & $17.46 \pm 0.81$ & $15.35 \pm 0.59$ & $13.66 \pm 0.45$ & $14.81 \pm 2.19$ \\
\hline Limonene* & 8.19 & 1029 & $0.18 \pm 0.04$ & $0.28 \pm 0.01$ & $0.34 \pm 0.01$ & $0.22 \pm 0.02$ & $0.10 \pm 0.07$ & $0.21 \pm 0.01$ & $0.06 \pm 0.07$ \\
\hline 1,8-Cineol & 8.38 & 1034 & $0.88 \pm 0.08$ & $0.54 \pm 0.02$ & $0.70 \pm 0.02$ & $0.65 \pm 0.03$ & $0.68 \pm 0.11$ & $0.82 \pm 0.02$ & $0.49 \pm 0.57$ \\
\hline$\gamma$-terpinene* & 9.20 & 1056 & $4.16 \pm 0.41$ & $4.13 \pm 0.13$ & $2.59 \pm 0.07$ & $3.75 \pm 0.10$ & $1.13 \pm 0.07$ & $4.97 \pm 0.03$ & $1.86 \pm 0.32$ \\
\hline trans-sabinene hydrate* & 9.73 & 1070 & $1.00 \pm 0.06$ & $0.20 \pm 0.02$ & $0.34 \pm 0.03$ & $0.25 \pm 0.04$ & $0.21 \pm 0.15$ & $1.04 \pm 0.07$ & $0.23 \pm 0.26$ \\
\hline Linalool & 10.76 & 1097 & $1.70 \pm 0.19$ & $1.72 \pm 0.07$ & $1.73 \pm 0.25$ & $1.50 \pm 0.23$ & $1.86 \pm 0.38$ & $1.52 \pm 0.21$ & $1.07 \pm 0.86$ \\
\hline Isoborneol* & 13.43 & 1163 & $0.62 \pm 0.07$ & $0.65 \pm 0.03$ & $0.72 \pm 0.06$ & $0.56 \pm 0.07$ & $1.12 \pm 0.21$ & $0.54 \pm 0.05$ & $0.48 \pm 0.29$ \\
\hline Terpinene-4-ol & 13.96 & 1175 & $0.18 \pm 0.02$ & $0.33 \pm 0.03$ & $0.31 \pm 0.04$ & $0.25 \pm 0.05$ & $0.32 \pm 0.21$ & $0.18 \pm 0.03$ & $0.14 \pm 0.16$ \\
\hline Thymol* & 18.81 & 1290 & $69.98 \pm 2.25$ & $65.78 \pm 0.54$ & $58.57 \pm 0.28$ & $67.76 \pm 0.55$ & $68.99 \pm 2.45$ & $70.00 \pm 0.34$ & $71.19 \pm 4.27$ \\
\hline Carvacrol* & 19.20 & 1300 & $4.90 \pm 0.15$ & $4.58 \pm 0.06$ & $5.02 \pm 0.10$ & $4.89 \pm 0.13$ & $5.35 \pm 0.23$ & $3.68 \pm 0.08$ & $7.16 \pm 1.45$ \\
\hline$\beta$-caryophyllene* & 23.68 & 1420 & $1.70 \pm 0.11$ & $0.89 \pm 0.08$ & $1.35 \pm 0.13$ & $0.97 \pm 0.13$ & $1.90 \pm 0.44$ & $1.43 \pm 0.013$ & $0.36 \pm 0.41$ \\
\hline cis- $\gamma$-cadinene & 27.49 & 1515 & n.d. & n.d. & n.d. & n.d. & $0.49 \pm 0.75$ & n.d. & n.d. \\
\hline trans-calamene* & 27.84 & 1525 & n.d. & n.d. & $0.08 \pm 0.09$ & n.d. & $0.21 \pm 0.14$ & n.d. & n.d. \\
\hline Caryophyllene oxide* & 30.20 & 1590 & $0.36 \pm 0.08$ & $0.51 \pm 0.06$ & $0.66 \pm 0.13$ & $0.46 \pm 0.10$ & $1.43 \pm 0.41$ & $0.19 \pm 0.05$ & $0.23 \pm 0.27$ \\
\hline -cadinol* & 32.26 & 1644 & $0.31 \pm 0.06$ & $0.23 \pm 0.04$ & $0.22 \pm 0.06$ & $0.17 \pm 0.11$ & $0.69 \pm 0.26$ & $0.22 \pm 0.06$ & $0.12 \pm 0.14$ \\
\hline $\begin{array}{l}\text { Monoterpene } \\
\text { hydrocarbons \% }\end{array}$ & & & 17.98 & 24.07 & 29.80 & 22.29 & 16.75 & 19.76 & 17.20 \\
\hline $\begin{array}{l}\text { Oxygenated } \\
\text { monoterpenes \% }\end{array}$ & & & 79.26 & 73.80 & 67.39 & 75.86 & 78.53 & 77.78 & 80.76 \\
\hline $\begin{array}{l}\text { Sesquiterpene } \\
\text { hydrocarbons \% }\end{array}$ & & & 1.70 & 0.89 & 1.43 & 0.97 & 2.60 & 1.43 & 0.36 \\
\hline $\begin{array}{l}\text { Oxygenated } \\
\text { sesquiterpenes \% }\end{array}$ & & & 0.67 & 0.74 & 0.88 & 0.63 & 2.12 & 0.41 & 0.35 \\
\hline Total detected \% & & & 99.61 & 99.50 & 99.50 & 99.75 & 100 & 99.38 & 98.67 \\
\hline
\end{tabular}

${ }^{a}$ Components are listed in order of elution from HP-5MS column; ${ }^{\mathrm{b}}$ Estimated linear retention indices on HP-5MS column

*The signed rows contain significantly different values $(p<0.05)$. Each value is the mean relative standard deviation of four replications. n.d. $=$ non-detectable

Summarizing the literature data and our own results, further analytic work is necessary in this field regarding the relative low numbers of researches have already been carried out. Even if convective drying is still the most wide-spread method, the new techniques, among them freezing and freezedrying are also in perspective, especially because of the organoleptic characteristics of the final products. Warm-air drying usually result in less colourful products, while frozen and lyophilized plant material has very similar colour and odour to the fresh plants. And a "fresh-looking" spice is more preferred by the consumers than a brownish coloured product, independently from its chemical features. Therefore the purpose of usage medicine, tea, tea mixture, capsule, spice determine which technique is desirable.

\section{Extraction methods influencing essential oil composition}

Thyme essential oil (Thymi aetheroleum Ph. Eur. 7.0) is traditionally isolated by hydrodistillation (HD), however, further techniques are also used to produce volatile-rich extracts or oleoresins from fresh or dried raw materials of thyme. The quality of thyme essential oil is affected by the method of distillation: water-distilled oils are commonly darker in colour and have stronger still notes than oils produced by other methods (Lawrence, 1995). The essential oil obtained directly from the aerial parts of T. vulgaris (common thyme) and T. zygis (Spanish thyme) is described as a brownish-red liquid exhibiting a strong aromatic odour and a warm, sharp flavour (red thyme oil). White thyme oil, however, is a pale yellow liquid obtained by rectification of the distilled red thyme oil, representing similar but milder odour and flavour characteristics. 
Numerous companies all over the world produce different extracted thyme products available on the market: e.g. standardized oleoresins, standardized emulsion oleoresin, encapsulated standardized oleoresins, etc. (Venskutonis, 2002). The extract quality and composition depend on the solvent nature, particularly its polarity and boiling temperature. The main constituents of the thyme oil are both polar (tyhmol, carvacrol) and non-polar ( $p$ cymene, $\quad \gamma$-terpinene) compounds. Beside conventional extraction procedures, such as solvent extraction and hydrodistillation, other optional isolation techniques are proposed as well, such as supercritical fluid extraction (SFE), solid phase microextraction (SPME) and solvent free microwave extraction (SFME).

Chemotype patterns as well as methods of extraction highly influence the results of antioxidant capacity and therapeutical applications. Among natural antioxidants, essential oils containing high amount of thymol or carvacrol (in Thymus, Origanum, Thymbra, Satureja) were reported to possess the highest antioxidant activity (Peltoketo et al., 2000). Rosmarinic acid accounted for $22-55 \%$ of the antioxidant effect of the ethanolic extract, while the essential oils with high proportion of thymol showed high antioxidant activity (Chizzola et al., 2008). Fecka et al. (2006) reported that aquaeous extracts of Serpylli herba and Thymi herba, containing salvianolic acid and rosmarinic acids as main compounds, showed significant antioxidant effect. They assumed that the activity of these compounds may be synergistic with those of the essential oil constituents. On the contrary, Lax et al. (2007) concluded that the best results regarding antioxidant capacity (DPPH assay) can be reached by a mixed chemotype, rich both in thymol and linalool instead of pure thymol (phenolic) chemotype of $T$. hyemalis.

\section{Supercritical fluid extraction (SFE)}

Concerning the modern industrial scale highpressure extraction techniques, supercritical fluid extraction (SFE) can successfully solve the main problems of conventional extraction procedures (organic solvent residues, degradation and hydrolysis of natural compounds at high temperature, artefacts, etc.). Carbon dioxide $\left(\mathrm{CO}_{2}\right)$ was found to be the most suitable solvent of SFE in various food applications, having significant advantages to alternatives. All dry botanicals containing oils and resins can be extracted with compressed $\mathrm{CO}_{2}$ : oleoresins are obtained, which can be fractionated into volatile oil and resin.

The main advantage of SFE over traditional extraction techniques is a possibility of continuous modulation of the solvent power/selectivity of the dense $\mathrm{CO}_{2}$, as well as elimination of polluting organic solvents and expensive post-processing of the extracts for elimination of solvent residue
(Reverchon \& De Marco, 2006). Therefore, the influence of the plant, growing conditions, harvest time and the part of the analyzed plant on the yield and chemical composition of extract must be considered as well (Santos-Gomes \& FernandesFerreira, 2001).

Thymus vulgaris was extracted by SFE- $\mathrm{CO}_{2}$ in several studies with different purposes. Cardoso et al. (1993) compared supercritical carbon dioxide (SFC) extraction to distillation methods, where higher yields were always obtained by the conventional distillation. Thymol was extracted at similar levels by all the tested methods, while the ratio of $p$-cymene was lower in SFE extracts.

Oszagyán et al. (1996) carried out supercritical fluid extraction of T. vulgaris under different extraction conditions. A stepwise increase of extraction pressure resulted in the fractionation of the extracts into liquid and pasty products. SFE samples contained thymol in much lower ratio (10-15 \%) than the hydrodistilled essential oil (48-50\%), while the carvacrol percent was higher (30-35\%) in SFE than in the distillate (8-10 \%). Similar results were found by Simándi et al. (1996) and Lemberkovics et al. (2001).

When comparing the extract yields obtained by supercritical fluid extraction to hydrodistillation, SFE was proven to be less effective, generally. Concerning T. vulgaris, Kutta et al. (2005) have found that the extract yield was considerably higher in the case of hydrodistilled (HD) oils than at SFE extracts. Both the extraction method and time influenced the extract yield and composition, while in all cases thymol was the main compound.

The SFE method decreased the ratio of $p$ cymene and, especially, of -terpinene, if compared to the HD volatile oil. Generally, SFE- $\mathrm{CO}_{2}$ extracts of thyme herbs represented wider spectra of both monoterpenes and of sesquiterpenes than the HD essential oils. The level of thymol was slightly lower in the SFEs $(<67.03 \%)$ than in the EO $(69.91$ $\%$ ). New monoterpene and sesquiterpene constituents have also been detected in the SFE extracts (e.g. geraniol, camphor, a -terpineol, $\alpha-$ bisabolol, $\beta$-caryophyllene, etc.) (Kutta et al. 2007) (Table 4).

Vági et al. (2002) studied the antimicrobial effects of SFE extracts against strains of foodderived pathogene fungi and bacteria. The SFE extracts of Thymus vulgaris exhibited considerable inhibitory activity against fungi (Aspergillus niger, Penicillium cyclopium \& Trichoderma viride), while complete growth inhibition was determined against bateria involved (Escherichia coli, Pseudomonas fluorescens \& Bacillus cereus). These results indicate that SFE extracts of thyme have a perspective as preservatives in food and cosmetic preparations.

It can be concluded that SFE method enable to isolate active substance comlpexes in near natural composition as well as to obtain 
Table 4. Composition of the volatile fractions obtained by SFE at different pressures (MPa) and of the distilled essential oil (HD) (after Kutta, 2007)

\begin{tabular}{|c|c|c|c|c|c|c|c|c|c|c|c|c|}
\hline \multirow{3}{*}{ Compounds } & \multicolumn{11}{|c|}{ Extraction pressure, MPa (SFE) } & \multirow{2}{*}{ HD } \\
\hline & 8 & 12 & 14 & 16 & 18 & 20 & 22 & 24 & 26 & 28 & 30 & \\
\hline & \multicolumn{12}{|c|}{ Ratio of compounds, \% (average values) } \\
\hline$\alpha$-pinene * & 0.14 & 0.20 & 0.20 & 0.06 & 0.09 & 0.18 & 0.16 & 0.25 & 0.25 & 0.08 & 0.37 & n.d. \\
\hline Camphene* & 0.14 & 0.12 & 0.12 & n.d & 0.06 & 0.12 & n.d. & 0.14 & 0.14 & n.d. & 0.21 & n.d. \\
\hline$\beta$-fellandrene* & 0.64 & 0.42 & 0.44 & 0.29 & 0.32 & 0.38 & 0.36 & 0.41 & 0.41 & 0.30 & 0.44 & n.d. \\
\hline$\beta$-pinene* & n.d. & n.d. & n.d. & n.d. & n.d. & n.d. & n.d. & 0.08 & n.d & n.d. & 0.12 & n.d. \\
\hline$\beta$-myrcene & n.d. & 0.69 & 0.78 & 0.28 & 0.39 & 0.67 & 0.57 & 0.70 & 0.73 & 0.25 & 0.90 & 0.46 \\
\hline$\alpha$-terpinene & 0.55 & 0.62 & 0.76 & 0.32 & 0.43 & 0.66 & 0.59 & 0.68 & 0.70 & 0,12 & 0.79 & 0.50 \\
\hline$p$-cymene & 11.33 & 8.82 & 8.86 & 4.49 & 6.20 & 8.08 & 7.40 & 7.72 & 8.85 & 4.95 & 10.10 & 9.99 \\
\hline Limonene & 0.39 & 0.33 & 0.36 & 0.15 & 0.23 & 0.33 & 0.30 & 0.33 & 0.37 & 0.15 & 0.43 & 0.18 \\
\hline 1,8-cineole & 0.78 & 0.51 & 0.63 & 0.30 & 0.34 & 0.54 & 0.39 & 0.51 & 0.52 & 0.29 & 0.60 & 0.52 \\
\hline$\gamma$-terpinene & 3.99 & 3.89 & 5.29 & 1.77 & 2.23 & 4.30 & 3.50 & 4.20 & 4.19 & 0.95 & 4.65 & 10.48 \\
\hline Terpinolene & n.d. & n.d. & n.d. & n.d. & n.d. & n.d. & n.d. & n.d. & n.d. & n.d. & n.d. & 1.13 \\
\hline trans-sabinene-hydrate* & 2.07 & 1.31 & 1.40 & 0.93 & 1.03 & 1.23 & 1.08 & 1.25 & 1.22 & 1.11 & 1.15 & n.d. \\
\hline Linalool & 3.74 & 2.23 & 2.47 & 0.81 & 1.92 & 2.05 & 1.87 & 1.97 & 2.06 & 1.98 & 1.99 & 1.69 \\
\hline Camphor* & 0.42 & 0.23 & 0.25 & 0.18 & 0.17 & 0.21 & 0.19 & 0.20 & 0.20 & 0.22 & 0.20 & n.d \\
\hline Borneol & 1.20 & 0.81 & 0.82 & 0.71 & 0.70 & 0.74 & 0.68 & 0.73 & 0.71 & 0.81 & 0.68 & 0.79 \\
\hline Terpinene-4-ol* & 0.43 & 0.28 & 0.31 & 0.29 & 0.26 & 0.26 & 0.25 & 0.26 & 0.25 & 0.30 & 0.27 & n.d. \\
\hline$\alpha$-terpineol* & 0.23 & 0.17 & 0.18 & 0.21 & 0.15 & 0,15 & 0.14 & 0.14 & 0.14 & 0.18 & 0.15 & n.d. \\
\hline Thymol metylether & n.d. & n.d. & n.d. & 0.08 & n.d. & n.d. & n.d. & n.d. & n.d. & n.d. & n.d. & 0.16 \\
\hline Carvacrol metylether & 0.79 & 0.49 & 0.54 & 0.37 & 0.38 & 0.43 & 0.35 & 0.37 & 0.41 & 0.38 & 0,38 & 0,15 \\
\hline Geraniol* & 0.48 & 0.41 & 0.41 & 0.43 & 0.44 & 0.43 & 0.44 & 0.46 & 0.50 & 0.56 & 0.39 & n.d \\
\hline Thymol & 54.01 & 51.27 & 54.98 & 62.16 & 67.03 & 60.61 & 66,17 & 54.73 & 59.80 & 57.31 & 58.57 & 69.91 \\
\hline Carvacrol & 3.79 & 3.85 & 4.18 & 4.70 & 5.07 & 4.57 & 5.07 & 4.20 & 4.60 & 4.55 & 4.52 & 2.39 \\
\hline Neryl acetate* & n.d. & n.d. & n.d. & 0.06 & 0.06 & n.d. & n.d. & n.d. & n.d. & 0.12 & n.d. & n.d. \\
\hline Geranyl acetate & n.d. & n.d. & n.d. & 0.06 & 0.07 & n.d. & n.d. & n.d. & n.d. & 0.11 & n.d. & 0.90 \\
\hline$\beta$-caryophyllene* & 4.15 & 2.83 & 3.13 & 2.34 & 2.43 & 2.65 & 2.46 & 2.42 & 2.69 & 2.42 & 2.53 & n.d. \\
\hline
\end{tabular}

* Compounds detected only in SFE extracts

n.d. = non-detectable

solvent free end products. This kind of plant extracts may play an important role in the prevention of diseases, as food additives, as well as they are suitable to realize therapeutic applications.

\section{Solid phase microextraction (SPME)}

Solid phase micro extraction is a simple and effective sample preparation method, also used as a headspace technique. It has several advantageous features; it is a fast, solvent free extraction method, having good selectivity and sensitivity, and because of its small size it can be used not only in the laboratory but also on-site (Bojko et al., 2012). It is possible to be connected directly to GC-MS and GC-FID systems, therefore after the sample preparation the composition of the volatile compounds can be analyzed immediately (Bicchi et al., 2000). In the case of aromatic plants, this method is rather useful, when the sample amount is not enough for the hydrodistillation. Referring to Thymus species this problem often emerges, since the analyzed wildgrowing populations sometimes contain only a few plants. Basically it needs to be emphasized that during this sampling technique the volatile compounds are directly absorbed onto an absorbent-coated fused silica fibre, and then desorbed into a GC injection port (Bicchi et al., 2000). Many fiber types are available assuring good selectivity of this method. Referring to garden thyme the most useful SPME fibres have already been analyzed; according to Bicchi et al. (2000) fibres consisted of a liquid (polydimethylsiloxane - PDMS) and a solid (divinylbenzene - DVB, carboxen - CAR) polymeric coating can be regarded as the most effective ones.

The sampling times and the applied temperatures are also variable. $1 \mathrm{~h}$ equilibration time at $60 \mathrm{C}$ was applied by Bicchi et al. (2000) using $0.6 \mathrm{~g}$ plant material hermetically sealed in a $12.5 \mathrm{ml}$ vial. In the research work of Dawidowicz et al. (2008) the fiber was introduced into a thermostated vial (at $25^{\circ} \mathrm{C}$ ) for $30 \mathrm{~min}$, using $2.0 \mathrm{~g}$ dried foliage. However, real optimization of the above mentioned parameters have not been carried out yet; therefore we initiated an analytic work in this field using $0.6 \mathrm{~g}$ dried plant material (grounded and crumbled); our first results can be seen in Table 5.

The sampling time, temperature and the plant material preparation (grounding, crumbling) 
Table 5. Composition of distilled thyme essential oil and SPME extracts obtained in the optimization experiment (after Sárosi and Ruff, 2013)

\begin{tabular}{|c|c|c|c|c|c|c|c|c|c|}
\hline Component $^{\mathrm{a}}$ & RT & $\mathbf{L R I}^{\mathrm{b}}$ & Distilled oil & 1 & 2 & 3 & 4 & 5 & 6 \\
\hline$\alpha$-thujene & 5.31 & 928 & $1.03 \pm 0.25$ & $1.29 \pm 1.56$ & $0.13 \pm 0.01$ & $0.38 \pm 0.27$ & $0.10 \pm 0.03$ & n.d. & $0.58 \pm 0.27$ \\
\hline$\alpha$-pinene & 5.56 & 938 & $0.68 \pm 0.03$ & $0.86 \pm 1.08$ & n.d. & $0.32 \pm 0.23$ & n.d. & n.d. & $0.30 \pm 0.30$ \\
\hline Camphene & 5.95 & 952 & $0.45 \pm 0.05$ & $0.68 \pm 0.79$ & n.d. & $0.26 \pm 0.16$ & n.d. & n.d. & $0.18 \pm 0.11$ \\
\hline Sabinene* & 6.52 & 976 & n.d. & $0.18 \pm 0.08$ & n.d. & n.d. & n.d. & n.d. & n.d. \\
\hline$\beta$-pinene* & 6.64 & 981 & $0.09 \pm 0.02$ & $0.22 \pm 0.15$ & n.d & $0.04 \pm 0.07$ & n.d. & n.d. & $0.03 \pm 0.05$ \\
\hline 1-octene-3-ol* & 6.81 & 987 & $0.60 \pm 0.13$ & $1.12 \pm 0.22$ & $0.92 \pm 0.06$ & $0.56 \pm 0.18$ & $1.35 \pm 0.17$ & n.d. & $0.07 \pm 0.12$ \\
\hline$\beta$-myrcene* & 6.99 & 995 & $1.09 \pm 0.03$ & $2.38 \pm 1.11$ & $0.35 \pm 0.01$ & $0.64 \pm 0.37$ & $0.21 \pm 0.04$ & n.d. & $0.65 \pm 0.39$ \\
\hline a-phellandrene* & 7.43 & 1008 & $0.05 \pm 0.01$ & $0.19 \pm 0.08$ & n.d. & $0.03 \pm 0.05$ & n.d. & n.d. & $0.02 \pm 0.04$ \\
\hline$\delta$-3-carene & 7.55 & 1011 & $0.01 \pm 0.02$ & $0.11 \pm 0.11$ & n.d. & n.d. & n.d. & n.d. & $0.01 \pm 0.02$ \\
\hline$a$-terpinene* & 7.79 & 1018 & $0.67 \pm 0.05$ & $1.66 \pm 0.57$ & $0.42 \pm 0.01$ & $0.48 \pm 0.19$ & $0.27 \pm 0.03$ & n.d & $0.54 \pm 0.31$ \\
\hline p-cymene* & 8.09 & 1026 & $38.36 \pm 0.73$ & $45.25 \pm 1.21$ & $28.30 \pm 1.83$ & $15.42 \pm 8.26$ & $27.00 \pm 1.98$ & $23.63 \pm 4.71$ & $33.32 \pm 8.81$ \\
\hline Limonene* & 8.19 & 1029 & $0.60 \pm 0.04$ & $1.20 \pm 0.29$ & $0.67 \pm 0.00$ & $0.50 \pm 0.14$ & $0.42 \pm 0.05$ & $0.34 \pm 0.59$ & $0.620 \pm .025$ \\
\hline 1,8-Cineol* & 8.38 & 1034 & $0.08 \pm 0.01$ & $0.55 \pm 0.05$ & $0.26 \pm 0.01$ & $0.27 \pm 0.05$ & $0.02 \pm 0.03$ & n.d. & $0.03 \pm 0.04$ \\
\hline$\underline{\gamma \text {-terpinene* }}$ & 9.20 & 1056 & $10.79 \pm 0.33$ & $19.85 \pm 0.97$ & $13.68 \pm 0.57$ & $6.99 \pm 1.57$ & $12.75 \pm 0.94$ & $7.03 \pm 0.99$ & $9.28 \pm 3.15$ \\
\hline trans-sabinene hydrate* & 9.73 & 1070 & $0.91 \pm 0.07$ & $2.32 \pm 0.63$ & $4.06 \pm 0.28$ & $2.11 \pm 0.07$ & $4.94 \pm 0.09$ & $0.40 \pm 0.70$ & $0.14 \pm 0.25$ \\
\hline trans-sabinene hydrate* & 9.73 & 1070 & $0.91 \pm 0.07$ & $2.32 \pm 0.63$ & $4.06 \pm 0.28$ & $2.11 \pm 0.07$ & $4.94 \pm 0.09$ & $0.40 \pm 0.70$ & $0.14 \pm 0.25$ \\
\hline$\alpha$-terpinolene* & 10.29 & 1085 & $0.01 \pm 0.01$ & $0.12 \pm 0.03$ & n.d. & n.d. & n.d. & n.d. & n.d. \\
\hline Linalool* & 10.76 & 1097 & $4.31 \pm 0.37$ & $6.44 \pm 1.96$ & $15.97 \pm 0.11$ & $6.08 \pm 0.28$ & $17.12 \pm 0.37$ & $7.28 \pm 7.83$ & $1.05 \pm 0.37$ \\
\hline Camphor* & 12.68 & 1144 & $0.66 \pm 0.06$ & $2.22 \pm 0.52$ & $2.71 \pm 0.00$ & $1.49 \pm 0.09$ & $2.44 \pm 0.07$ & $0.48 \pm 0.83$ & $0.06 \pm 0.11$ \\
\hline Isoborneol* & 13.43 & 1163 & $0.33 \pm 0.10$ & $0.45 \pm 0.23$ & $1.31 \pm 0.15$ & $1.08 \pm 0.07$ & $1.31 \pm 0.07$ & n.d. & n.d. \\
\hline Terpinene-4-ol* & 13.96 & 1175 & $0.25 \pm 0.07$ & $0.16 \pm 0.15$ & $0.41 \pm 0.05$ & $0.31 \pm 0.04$ & $0.27 \pm 0.15$ & n.d. & n.d. \\
\hline$\alpha$-terpineol* & 14.55 & 1189 & n.d. & n.d. & $0.20 \pm 0.04$ & n.d. & $0.14 \pm 0.03$ & n.d. & n.d. \\
\hline Thymol methylether* & 16.20 & 1228 & n.d. & $0.07 \pm 0.06$ & $0.08 \pm 0.11$ & $0.19 \pm 0.02$ & $0.15 \pm 0.02$ & n.d. & $0.03 \pm 0.05$ \\
\hline Carvacrol methylether* & 16.61 & 1238 & $0.12 \pm 0.03$ & $0.57 \pm 0.13$ & $0.86 \pm 0.07$ & $0.80 \pm 0.06$ & $0.84 \pm 0.05$ & n.d. & $0.08 \pm 0.13$ \\
\hline Bornylacetate* & 18.41 & 1281 & $0.14 \pm 0.13$ & $0.20 \pm 0.05$ & $0.25 \pm 0.03$ & $0.42 \pm 0.04$ & $0.22 \pm 0.05$ & n.d. & n.d. \\
\hline Thymol* & 18.81 & 1290 & $32.47 \pm 0.43$ & $4.86 \pm 1.55$ & $16.87 \pm 1.21$ & $18.92 \pm 2.29$ & $17.20 \pm 2.16$ & $28.61 \pm 13.98$ & $20.87 \pm 8.37$ \\
\hline Carvacrol ethylether* & 18.95 & 1294 & $0.64 \pm 0.04$ & n.d. & $0.45 \pm 0.04$ & $0.47 \pm 0.07$ & $0.29 \pm 0.12$ & n.d. & $0.08 \pm 0.14$ \\
\hline Carvacrol* & 19.20 & 1300 & $2.69 \pm 0.08$ & $0.22 \pm 0.20$ & $1.38 \pm 0.14$ & $1.96 \pm 0.26$ & $1.20 \pm 0.20$ & $2.04 \pm 0.48$ & $1.83 \pm 0.73$ \\
\hline$\overline{\alpha \text {-copaene* }}$ & 22.03 & 1377 & n.d. & n.d. & n.d. & $0.22 \pm 0.02$ & n.d. & n.d. & n.d. \\
\hline$\beta$-bourbonene* & 22.26 & 1383 & n.d. & $0.18 \pm 0.03$ & $0.27 \pm 0.06$ & $0.81 \pm 0.09$ & $0.22 \pm 0.22$ & n.d. & $0.06 \pm 0.10$ \\
\hline$\beta$-caryophyllene* & 23.68 & 1420 & $1.86 \pm 0.05$ & $4.55 \pm 1.14$ & $8.51 \pm 0.95$ & $17.39 \pm 1.75$ & $9.74 \pm 0.78$ & $3.00 \pm 2.65$ & $4.40 \pm 1.28$ \\
\hline Aromadendrene* & 24.58 & 1442 & n.d. & n.d. & n.d. & $0.13 \pm 0.03$ & n.d. & n.d. & n.d. \\
\hline$\alpha$-humulene* & 25.07 & 1454 & n.d. & $0.05 \pm 0.04$ & n.d. & $0.76 \pm 0.07$ & $0.02 \pm 0.04$ & n.d. & n.d. \\
\hline Alloaromadendrene* & 25.39 & 1462 & n.d. & n.d. & n.d. & $0.16 \pm 0.04$ & n.d. & n.d. & $0.07 \pm 0.12$ \\
\hline$\gamma$-muurolene* & 25.99 & 1477 & n.d. & $0.02 \pm 0.03$ & n.d. & $1.29 \pm 0.13$ & n.d. & n.d. & $0.06 \pm 0.10$ \\
\hline Germacrene-D* & 26.18 & 1482 & n.d. & $0.13 \pm 0.02$ & $0.20 \pm 0.07$ & $1.81 \pm 0.15$ & $0.16 \pm 0.04$ & n.d. & $0.18 \pm 0.16$ \\
\hline Viridiflorene* & 26.76 & 1496 & n.d. & n.d. & n.d. & $0.22 \pm 0.19$ & n.d. & n.d. & n.d. \\
\hline Bicyclogermacrene* & 26.81 & 1497 & n.d. & n.d. & n.d. & $0.71 \pm 0.28$ & n.d. & n.d. & $0.05 \pm 0.08$ \\
\hline a-muurolene* & 26.97 & 1501 & n.d. & n.d. & n.d. & $0.28 \pm 0.03$ & n.d. & n.d. & n.d. \\
\hline$\beta$-bisabolene* & 27.23 & 1508 & n.d. & n.d. & n.d. & $0.17 \pm 0.04$ & n.d. & n.d. & n.d. \\
\hline cis- $\gamma$-cadinene* & 27.49 & 1515 & n.d. & $0.01 \pm 0.01$ & n.d. & $0.84 \pm 0.09$ & n.d. & n.d. & $0.04 \pm 0.07$ \\
\hline$\delta$-cadinene* & 27.80 & 1524 & $0.02 \pm 0.03$ & $0.04 \pm 0.04$ & n.d. & $1.54 \pm 0.18$ & $0.03 \pm 0.05$ & n.d. & $0.25 \pm 0.21$ \\
\hline Spathulenol* & 29.98 & 1584 & n.d. & n.d. & n.d. & $0.33 \pm 0.06$ & n.d. & n.d. & n.d. \\
\hline Caryophyllene oxide* & 30.20 & 1590 & $0.73 \pm 0.08$ & n.d. & n.d. & $3.21 \pm 0.57$ & n.d. & n.d. & $0.97 \pm 0.41$ \\
\hline Epi-a-bisabolol* & 34.00 & 1690 & $0.15 \pm 0.04$ & n.d. & n.d. & $0.45 \pm 0.39$ & n.d. & n.d. & n.d. \\
\hline $\begin{array}{l}\text { Monoterpene } \\
\text { hydrocarbons \% }\end{array}$ & & & 53.83 & 73.87 & 43.55 & 25.06 & 40.75 & 31.00 & 45.53 \\
\hline $\begin{array}{l}\text { Oxygenated } \\
\text { monoterpenes \% }\end{array}$ & & & 43.20 & 19.30 & 45.73 & 33.58 & 47.49 & 38.81 & 24.24 \\
\hline $\begin{array}{l}\text { Sesquiterpene } \\
\text { hydrocarbons \% }\end{array}$ & & & 1.88 & 5.07 & 8.98 & 26.66 & 10.17 & 3 & 5.11 \\
\hline $\begin{array}{l}\text { Oxygenated } \\
\text { sesquiterpenes \% }\end{array}$ & & & 0.88 & 0 & 0 & 3.66 & 0 & 0 & 0.97 \\
\hline Total detected \% & & & 99.79 & 98.24 & 98.26 & 88.96 & 98.41 & 72.81 & 75.85 \\
\hline
\end{tabular}

influenced significantly the ratios of the compounds could be detected by the GC-MS system with the exception of only a few compounds: $\alpha$ thujene, $\alpha$-pinene, camphene and $\delta$-3-carene. Incubation at $60^{\circ} \mathrm{C}$ for 60 minutes produced much higher ratios of sesquiterpenes in the final chromatograms; probably because of the high temperature and long sampling time the fibre coating characteristics have been changed. Obviously, the grounded plant materials (signed by 
1,2,3 and 4) had more complex aroma profile; in the crumbled samples the concentration of the volatile compounds were lower in the HS, and higher percentages of siloxane derivatives could be seen coming from the fibre coating.

Even if in the previous literature data, the ratio of thymol in the headspace was much lower than in the distilled essential oil (Venskutonis, 1997; Dawidowicz et al., 2008; Bertoli et al., 2010); the authors underlined that the sampling method should have been optimized. Indeed, according to our results the thymol ratios almost reach that one measured in the distilled oil in two cases (crumbled drug, incubation time $30 \mathrm{~min}$, temperature 25 and $60^{\circ} \mathrm{C}$ ).

More significant differences were detected referring to the linalool ratios. Surprisingly, the results were rather variable; the percentages varied between $1.05-17.12 \%$, approximately. The highest results were got in the case of the grounded drugs, by applying relative low sampling time and temperature. Hydrodistillation and higher sampling temperature (at $60^{\circ} \mathrm{C}$ ) influenced negatively the ratio of this compound.

Short sampling time and low temperature is more advantageous to the monoterpene hydrocarbons: during the first treatment the percentage of the detected monoterpene hydrocarbons reached $73.87 \%$ that significantly exceeded the results measured in the distilled oil (53.83\%).

Summarizing our results, the applied SPME method should be optimized in the case of different plant species. For the evaluation of the volatile constituents the Pharmacopoeia still describes hydrodistillation as the only acceptable extraction technique. Therefore if the use of an alternative technique is necessary (mainly because of the low amount of plant material, lack of time or proper equipment) an adequate method needs to be developed getting comparable result of the conventional hydrodistillation. From this point of view it is advisable to apply longer sampling time (30 $\mathrm{min}$ ) and heating $\left(60^{\circ} \mathrm{C}\right)$, and not powder the plant material before the analysis.

\section{Conclusions}

According to the review of the available literature on factors influencing composition and biological activity of thyme essential oil, we can conclude that genetic features, environmental and growing conditions as well as processing technologies have all significant effect of the final product and quality parameters.

Concerning genetic background, the presence of different chemotypes with distinct chief compounds in the essential oil basically influence the areas of utilization. The main constituent of commercial thyme oil is predominantly thymol with the highest therapeutical relevance attributed to Thymus species. Therefore, breeding efforts have been made in order to develop varieties with high essential oil content as well as elevated thymol percentage. Regarding growing conditions and agrotechnical procedures, it can be established that higher essential oil content and thymol ratio can be expected at full bloom, at first (spring) harvest, especially in young thyme fields. Weather has also significant effect on essential oil properties, as sunny and dry periods accelerate thymol biosynthesis prior to harvest. In the case of further chemotypes with 1,8-cineole as main compound, the appropriate cutting period is in the mid-vegetative stage, while terpenyl acetate, $a-$ terpineol and linalool, associated with fresh aroma, are highly concentrated from full bloom to advanced fruit formation. Nitrogen fertilizers increased total biomass and consequently, resulted in elevated essential oil yields referring to unit area.

According to the recent results, processing technologies, especially drying methods influence significantly the quantity and quality parameters of the essential oil in the final product. Higher amount of essential oil can be obtained by drying at low temperature (natural way or by convecting drying at $30^{\circ} \mathrm{C}$ ), while lyophilisation (freeze drying) is the best method to preserve thymol and carvacrol in higher ratios. Even if convective drying is still the most wide-spread method, the new techniques, freezing and freeze-drying are also in perspective, especially because of the desirable organoleptic characteristics of the final products.

After primary processing, dried thyme herb can be stored at a maximum temperature of $10 \mathrm{C}$ without considerable essential oil loss, as with increasing temperature, the declination of the essential oil content is more significant. The essential oil composition also changes during storage, especially the loss of the valuable monoterpenes was observed.

Beside conventional extraction techniques, such as solvent extraction and hydrodistillation (HD), further isolation methods have already been developed and resulted in modified extract composition. When comparing the extract yields obtained by supercritical fluid extraction (SFE) to hydrodistillation, SFE was proven to be less effective, while in all cases thymol was the main compound but with slightly lower level in the SFEs $(<67.03 \%)$ than in the EO (69.91\%). In general, SFE- $\mathrm{CO}_{2}$ extracts of thyme herbs represented wider spectra of both monoterpenes and of sesquiterpenes than the HD essential oils. This method is applied in industrial scale when natural aroma compounds are extracted from thyem herb. In contrast, solid phase micro extraction (SPME) is a simple and effective laboratory scale sample preparation method with several advantageous features, optimized for thyme plant for fast and reliable results on essential oil composition even 
from very small amount of experimental or industrial samples.

\section{Competing Interest}

The authors declare that they have no competing interests.

\section{Authors' contributions}

ZP coordinated the work interpreted the results on genetic factors, environmental and growing conditions as well as on supercritical fluid extraction. SS provided informations and research data on the utilization, processing and SPME technics, while DZ contributed in finalization and correction of the manuscript. All authors read and approved the final content of the manuscript. ZP submitted the final script through his account

\section{Acknowledgements}

Our studies cited in this chapter have been supported by the National Scientific Fund (under the project no. OTKA F 043555 and OTKA PD 73290), Bolyai János Scientific Fund (2008-2011) and the authors are also very thankful to the subsidy of the projects GOP-2007-1.1.1. and TÁMOP-4.2.1/B-09/1/KMR-2010-0005.

\section{References}

Aeschbach, R., J. Löliger, B. C. Scott, A. Murcia, J. Butler, and B. Halliwell. 1994. Antioxidant actions of thymol, carvacrol, 6-gingerol, zingerone and hydroxytyrosol. Food and Chemical Toxicology 32: 31-36. doi:10.1016/0278-6915(84)90033-4

Anonymous. 2008. Rapport d'Activité 2008. ITEIPMAI (L’Organisme Français de Recherche pour le Dévéloppement des Plantes à Parfum, Médicinales et Aromatiques. p. 12-13.

Anonymous. 2011. Pharmacopoeia Europea. $7^{\text {th }}$ Edition. p. 1252; 1254. ISBN: 9287167060

Balladin, D. A. and Headley O. 1999. Evaluation of solar dried thyme (Thymus vulgaris Linné) herbs. Renewable Energy 17: 523-531. doi:10.1016/S09601481(98)00757-5

Baranauskiené, R., Venskutonis, P. R., Viskelis, P. and Dambrauskiené, E. 2003. Influence of nitrogen fetilizers on the yield and composition of thyme (Thymus vulgaris). Journal of Agricultural and Food Chemistry 51: 7751-7758. doi: 10.1021/jf0303316

Bardeau, F. 1973. La pharmacie de bon Dieu, Stock, Paris, p. 279-281.

Baser K., Kirimer N., Ermin N and Özek, T. 1996. Composition of essential oils from three varieties of Thymus praecox Opiz growing in Turkey. Journal of Essential Oil Research 9: 319-321. doi: 10.1080/10412905.1996.9700624

Begrow, F., Engelbertz J., Feistel B., Lehnfeld R., Bauer K. and Verspohl E.J. 2010. Impact of Thymol in thyme extracts on their antispasmodic action and ciliary clearance. Planta Medica 76: 311-318. doi: 10.1055/s-0029-1186179

Bertoli, A., Sárosi Sz., Bernáth J. and Pistelli L. 2010. Characterization of some Italian ornamental
Thyme by their aroma. Natural Product Communications 5: 291-296.

Bicchi, C., Drigo S. and Rubiolo P. 2000. Influence of fibre coating in headspace solid-phase microextractiongas chromatographic analysis of aromatic and medicinal plants. Journal of Chromatography $A$. 892: 469-485. doi:10.1016/S0021-9673(00)00231-4

Bojko, B., Cudjoe E., Gómez-Ríos G. A., Gorynski K., Jiang R., Reyes-Garcés N., Risticevic S., Silva É. A. S., Togunde O., Vuckovic D. and Pawliszyn J. 2012. SPME - Quo vadis? Analitica Chimica Acta 750: 132-151. doi:10.1016/j.aca.2012.06.052

Böttcher, H., Günther I. and Kabelitz L. 2001. Physiological postharvest response of thyme (Thymus vulgaris L.) herbs. Gartenbauwissenschaft 66: 172-181.

Braga PC, Dal Sasso, M., Culici M. and Spallino, A. 2010. Inhibitory activity of thymol on native and mature Gardnerella vaginalis biofilms: in vtro study. Arzneimittelforschung 60 (11): 675-681. doi: 10.1055/s-0031-1296346

Cakir, A., Kordali S., Kilic H. and Kaya E. 2005. Antifungal properties of essential oil and crude extracts of Hypericum linairoides Bosse. Biochemical Systematics and Ecology 33: 245-256. doi:10.1016/j.bse.2004.08.006

Cardoso, L. A., Moldao-Martins, M., Bernardo-Gil, G. and Beirao da Costa, M.L. 1993. Supercritical fluid extraction of aroma compounds from aromatic herbs (Thymus zygis and Coriandrum sativum). In: Development in Food Engineering, $6^{\text {th }}$ Int. Congress on Engineering and Food, Chiba, Japan, p. 829-831.

Carlen, C., Schaller, M., Carron, C. A., Vouillamoz, J. and Baroffio, C.A. 2010. The new Thymus vulgaris L. hybrid cultivar 'Varico 3' compared to five established ultivars from Germany, France and Switzerland. Acta Horticulturae 860: 161-166. doi: 10.17660/ActaHortic.2010.860.23

Chizzola, R., Michitsch, H. and Franz, Ch. 2008. Antioxidative properties of Thymus vulgaris leaves: Comparison of different extracts and essential oil chemotypes. Journal of Agricultural and Food Chemistry 56: 6897-6904. doi: 10.1021/jf800617g

Crocoll, C., Ashbach, J., Novak, J., Gershenzon, J. and Degenhardt, J. 2010. Terpene synthases of oregano (Origanum vulgare L.) and their roles in the pathway and regulation of terpene biosynthesis. Plant Molecular Biology 73: 587-603. doi: 10.1007/s11103-010-9636-1

Dajić-Stevanović, Z., Šoštarić I., Marin P. D., Stojanović D. and Ristić M. 2008. Population variability in Thymus glabrescens, Willd. from Serbia: morphology, anatomy and essential oil composition. Archives of Biological Science Belgrade 60: 475-483. doi:10.2298/ABS0803475D

Dawidowicz, A. L., Rado E., Wianowska D., Mardarowicz M. and Gawdzik J. 2008. Application of PLE for the determination of essential oil components from Thymus vulgaris L.. Talanta 76: 878-884. doi:10.1016/j.talanta.2008.04.050

Deans, S. G., Noble R. C., Pénzes L. and Imre G.G. 1993. Promotional effects of plant volatile oils and the polyunsaturated fatty-acid. Age 16: 71-74. doi: 10.1007/BF02435040 
Deans, S. G., Noble R. C., Pénzes L.G. and Imre S. G. 1994. A new type of approach to modify lipid patterns in ageing mice: Natural antioxidants of plant origin. In: Vienna Ageing Series. $4^{\text {th }}$ edition. G. Hofecker and M. Skalicky, Eds. Vienna, Facultas Press. p. 173-177.

Diaz-Maroto, M.C., Pérez-Coello, M.S and Cabezudo, M.D. 2002. Effect of different drying methods on the volatile components of parsley (Petroselinum crispum L.) European Food Research and Technology 215:227-230. doi: 10.1007/s00217-0020529-7

Dorman, H. J. D., Deans S.G., Noble R.C. and Sera H. 1995. Evaluation in vitro of plant essential oils as natural antioxidants. Journal of Essential Oil Research 7: 645-650. doi: 10.1080/10412905.1995.9700520

Dorman, H.J.D., Surai P. and Deans S.G. 2000. In vitro antioxidant activity of number of plant essential oils and phytoconstituents. Journal of Essential Oil Research 12: 241-248. doi: 10.1080/10412905.2000.9699508

Echeverrigaray, S., Agostini, G., Atti-Serfini, L., Paroul, N., Pauletti, G.F. and Dos Santos, A.C.A. 2001. Correlation between the chemical and genetic relationships among commercial thyme cultivars. Journal of Agricultural and Food Chemistry 49: 4220-4223. doi: 10.1021/jf010289j

Fachini-Queiroz, F.C., Kummer R., Estevão-Silva C.F., Carvalho M.D.D.B., Cunha J.M., Grespan R., Bersani-Amado C.A. and Cuman R.K.N. 2012. Effects of thymol and carvacrol, constituents of Thymus vulgaris L. essential oil, on the inflammatory response. Evidence-based Complementary and Alternative Medicines Article number: 657026 doi:10.1155/2012/657026

Fecka, I., Cisowski, W., Sroka, Z. and Kowalczyk, A. 2006. The presence of polyphenolic compounds in some volatile oil containing plants and their biological activities. $37^{\text {th }}$ International symposium on Essential Oils, Grasse, France, September 10-13, 2006. Book of Abstracts, p. 66.

Fernandes, E. S., Passos G. F., Medeiros R., M. da Cunha F., Ferreira J., Campos M. M., Pianowski L. F. and Calixto J. B. 2007. Anti-inflammatory effects of compounds alpha-humulene and (-)-transcaryophyllene isolated from the essential oil of Cordia verbenacea. European Journal of Pharmacology doi:10.1016/j.ejphar.2007.04.059

Figueiredo, A. C., Barroso, J. G., Pedro, L. G., Salgeiro, M. G. and Faleiro, M. I. 2008. Portugese Thymbra and Thymus species volatiles: chemical composition and biological activities. Current Pharmaceutical Design 14: 3120-3140. doi: http://dx.doi.org/10.2174/138161208786404218

Furlenmeimer, M (1984) Plantas curativas y sus propiedades medicinales. Zug: Schwittez, 168.

García, M., Gonzalez-Coloma A., Donadel O. J., Ardanaz C. E., Tonn C. E. and Sosa M. E. 2007. Insecticidal effects of Flourensia oolepis Balke (Asteraceae) essential oil. Biochemical Systematics and Ecology 35: 181-187. doi:10.1016/j.bse.2006.10.009

Gouyon, P. H., Vernet, P., Guillery, J. L. and Valdeyron, G., 1986. Polymorphism and environment: the adaptive value of the oil polymorphism in Thymus vulgaris L. Heredity 57: 59-66.
Granger, R. and Passet, J. 1971. Types chimique (chémotypes) de l'espèce Thymus vulgaris L., C. $R$. Acad. Sci. Paris 273: 2350-2353.

Granger, R. and Passet, J. 1973. Thymus vulgaris L. spontane de france: races chimiques et chemotaxonomie, Phytochemistry 12: 1683-1691. doi:10.1016/0031-9422(73)80388-7

Heeger, E.F. 1989. Handbuch des Arznei- und Gewürzpflanzenbaues (Drogengewinnung). Berlin: VEB Deutscher Landwirtschaftsverlag, 673-677.

Hegnauer, R. 1978. Die systematische Bedeutung der ätherischen Öle (Chemotaxonomie der äterischen Öle), Dragoco Rep., 204-230 pp.

Hernández L. M., Tomás-Barberán F. A., Tomás-Lorente F. 1987. A chemotaxonomic study of free flavone aglycones from some Iberian Thymus species. Biochemical Systemtics and Ecology 15: 61-67. doi:10.1016/0305-1978(87)90081-0

Horváth, B., Mukhopadhyay P., Kechrid M., Patel V., Tanchian G., Wink D. A., Gertsch J. and Pacher P. 2012. $\beta$-caryophyllene ameliorates cisplatininduced nephrotoxicity in a cannabinoid 2 receptor-dependent manner. Free Radical Biology \& Medicine 52: 1325-1333. doi:10.1016/j.freeradbiomed.2012.01.014

Hudaib, M., Speroni, E., Di Pietra, A. M. and Cavrini, V. 2002. GC/MS evaluation of thyme (Thymus vulgaris L.) oil composition and variations during the vegetation cycle. Journal of Pharmaceutical and Biomedical Analysis 29: 691-700. doi:10.1016/S0731-7085(02)00119-X

Ince, A.G., Elmasulu, S., Cinar, A., Karaca, M., Onus, A. N. and Turgut, K. 2009. Comparison of DNA marker techniques for Lamiaceae. Acta Horticulturae 826: 437-445. doi: 10.17660/ActaHortic.2009.826.61

Jordán, M. J., Martínez, R. M., Goodner, K. L., Baldwin, E. A. and Sotomayor, J. A. 2006. Seasonal variation of Thymus hyemalis Lange and Spanish Thymus vulgaris L. essential oils composition. Industrial Crops and Products 24: 253-263. doi:10.1016/j.indcrop.2006.06.011

Karaca, M., Ince, A. G., Turgul, S., Turgut, K. and Onus, A. N. 2008. PCR-RFLP and DAMD-PCR genotyping for Salvia species. Journal of Science in Food and Agriculture 88: 2508-2516. doi: 10.1002/jsfa.3372

Kamondy L., Pluhár Zs., Ferenczy A. and Sárosi Sz. 2005. Kerti kakukkfü (Thymus vulgaris L.) törzsek produkcióbiológiai értékelése (Production biological evaluation of garden thyme (Thymus vulgaris L.) lines). Kertgazdaság 37 (Special issue): 197-207.

Khazaie, H. R., Nadjafi, F. and Bannayan, M. 2008. Effect of irrigation and plant density on herbage biomass and oil production of thyme (Thymus vulgaris) and hyssop (Hyssopus officinalis). Industrial Crops and Products 27: 315-321. doi:10.1016/j.indcrop.2007.11.007

Kutta G., Pluhár Zs. and Héthelyi É. (2005). Különböző eredetű kakukkfű fajok (Thymus spp.) desztillált és szuperkritikus szén-dioxid extrakcióval kinyert kivonatainak összehasonlító értékelése. Olaj, Szappan, Kozmetika 54: 180-186.

Kutta, G., Pluhár Zs. and Sárosi Sz. 2007. Yield and composition of supercritical fluid extracts of different Lamiaceae herbs. International Journal of Horticultural Science 13: 79-82. 
Lax, V., Jordán, M. J., Martínez, C., Moñino, M. I., Martínez, R. M. and Sotomayor, J. A. 2007. Chemical variability and radical scavenging activity of Thymus hyemalis L. essential oil cultivated at the Region of Murcia (Spain). $38^{\text {th }}$ International Symposium on Essential Oils. Graz, Austria.

Lawrence, B. M. 1995. The isolation of aromatic materials from natural plant products. In: $A$ Manual on the Essential Oil Industry. K. Tuley da Silva, Ed. UNIDO. Vienna, Austria. p- 57-154.

Lemberkovics, É., Kéry, Á., Simándi, B., Kristo, T.S., Kakasy, A. and Szőke, É. 2001. Evaluation of supercritical plant extracts on volatile and non-volatile biologically active lipophil components. International Journal of Horticultural Science, 7 (2): 78-83.

Leonhardt, V., Leal-Cardoso J. H., Lahlou S., Albuqeurque A. A., Porto R. S., Celedonio N. R., Oliveira A. C., Pereira R .F., Silva L. P., GarciaTeofilo T. M., Silva A. P., Magalhaes P. J., Duarte G. P. and Coelho-de-Souza A. N. 2010. Antispasmodic effects of essential oil of Pterodon polygalaeflorus and its main constituent $\beta$-caryophyllene on rat isolated ileum. Fundamental \& Clinical Pharmacology 24: 749-758. doi: 10.1111/j.14728206.2009.00800.x

Mantle, D., Anderton J. G., Falkous G., Barnes M., Jones P. and Perry E. K. 1998. Comparison of methods for determination of total antioxidant status: application to analysis of medicinal plant essential oils. Comparative Biochemistry and Physiology Part B 121: 385-391. doi:10.1016/S0305-0491(98)10120-7

Marin D. P. 1996. A chemotaxonomic study of vacuolar flavonoids from some Balkan Micromeria species (Lamiaceae). Arch. Biol. Sci. (Belgrade), 48: 49-54.

Marin D. P., Grayer J. R., Kite C. G. and Matevski V. 2003. External leaf flavonoids of Thymus species from Macedonia. Biochemical Systematics and Ecology 31:1291-1307. doi:10.1016/S0305-1978(03)00040-1

Moreira Galdino, P., Nascimento M. V. M., Ferreira Florentino I., Campos Lino R., Oluwagbamigbe Fajemiroye J., Abdallah Chaibub B., Realino de Paula J., Monteiro de Lima T. C. and Costa E. A. 2012. The anxiolytic-like effect of an essential oil derived from Spiranthera odoratissima A. St. Hil. leaves and its major component, $\beta$-caryophyllene, in male mice. Progress in NeuroPsychopharmacology \& Biological Psychiatry 38: 276-284. doi:10.1016/j.pnpbp.2012.04.012

Morales, R. 2002. The history, botany and taxonomy of the genus Thymus. In: Thyme. The Genus Thymus. Stahl-Biskup, E., Sáez, F. Eds. Taylor Francis. London - New York. p. 16-17.

Nowak, A., Kalemba D., Piotrowska M. and Czyzowska A. 2012. The effects of thyme (Thymus vulgaris) and rosemary (Rosmarinus officinalis) essential oils on Brochothrix thermosphacta and on the shelf life of beef packaged in high-oxygen modified atmosphere. Food Microbiology 32: 212-216. doi:10.1016/j.fm.2012.05.001

Oszagyán, M., Simándi B., Sawinsky J. and Kéry Á., Lemberkovics E., Fekete J. 1996. Supercritical fluid extraction of volatile compounds from lavandin and thyme. Flavour and Fragrance
Journal 11: 157-165. 10.1002/(SICI)10991026(199605)11:3<157::AID-FFJ559>3.0.CO;2-6

Panizzi, L., Flamini, G., Cioni, P.L. and Morelli, I. 1993. Composition and antimicrobial properties of essential oils of four Mediterranean Lamiaceae. Journal of Ethnopharmacology 39: 167-170. doi:10.1016/0378-8741(93)90032-Z

Pank, F. and Krüger, H. 2003. Sources of variability of thyme (Thymus vulgaris L) populations and conclusion for breeding. Z. Arzn. Gew. Pfl. 8: 117124.

Peltoketo, A., Dorman, H. J. D., Yrjönen, T., Sumanen, J., Laakso, I., Vuorela, H. and Hiltunen, R. 2000. Antioxidant properties of volatile oil and aqueous fractions of selected medicinal plants. Phytomedicine, Supplement II. 75 pp.

Pérez-Sánchez, R., Ubera, J. L., Lafont, F. and Gálvez, C. 2008. Composition and variability of the essential oil in Thymus zygis from southern Spain. Journal of Essential Oil Research 20: 192-200. doi: 10.1080/10412905.2008.9699989

Perrot, E. and Paris, R. 1971. Les plantes medicinales. Presses Universitaires de France, Paris, p. 233.

Poletti, A. 1979 Plantas y Flores Medicinales. Instituto Parramon, Barcelona, p. 103-104.

Pluhár, Zs., Simkó, H., Kovács, K., Vida, Sz., György, Zs. and Sárosi, Sz. 2010. Essential oil composition of selected Thymus vulgaris L. clones belonging to five chemotypes. $41^{\text {th }}$ International Symposium on Essential Oils. September 5-8, 2010. Wroclaw, Poland. Abstracts. p. 80.

Raghavan, B., Abraham K. O. and Koller W. D. 1995. Flavour quality of fresh and dried Indian thyme (Thymus vulgaris L.). Pafai Journal 17:9-14.

Rahimmalek, M. and Goli S. A. H. 2013. Evaluation of six drying treatments with respect to essential oil yield, composition and color characteristics of Thymys daenensis subsp. daenensis. Cleak leaves. Industrial Crops and Products 42: 613-619. doi:10.1016/j.indcrop.2012.06.012

Recsan, Zs., Pagliuca G., Piretti M. V., Pénzes L. G., Youdim K. A., Noble R. C. and Deans S. G. 1997. Effect of essential oils on the lipids of the retina in the ageing rat: a possible therapeutic use. Journal of Essential Oil Research 9: 53-56. doi: 10.1080/10412905.1997.9700714

Reverchon, E. and De Marco, I. 2006. Supercritical fluid extraction and fractionation of natural matter. The Journal of Supercritical Fluids 38:146-166. doi:10.1016/j.supflu.2006.03.020

Rey, C. 1993. Hybrides de thym prometteurs pour la montagne. Revue Suisse Vitic. Arboric., Hortic. 25: 269-275.

Rey, C., Carron, C. A., Cottagnaud, A., Schweitzer, N., Bruttin, B., and Carlen, C. 2004. Nouveaux hybrides de thym vulgaire. Revue Suisse Vitic. Arboric., Hortic. 36: 297-301.

Ruberto, G. and Baratta M. T. 2000. Antioxidant activity of selected essential oil components in two lipid model systems. Food Chemistry 69: 167-174. doi:10.1016/S0308-8146(99)00247-2

Sacchetti, G., Maietti S., Muzzoli M., Scaglianti M., Manfredini S., Radice M. and Bruni R. 2005. Comparative evaluation of 11 essential oils of different origin as functional antioxidants, antiradicals and antimicrobials in foods. Food 
Chemistry

90:

$621-632$

doi:10.1016/j.foodchem.2004.06.031

Sáez, F. 1998. Variability in essential oils from populations of Thymus hyemalis Lange in southeastern Spain. Journal of Herbs, Spices \& Medicinal Plants 5: 65-76. doi: 10.1300/J044v05n04_08

Sárosi, Sz., Bernáth, J. 2008. The effect of weather conditions on the essential oil and total phenol content of different Thymus vulgaris L. cultivars. $39^{\text {th }}$ International symposium on Essential Oils. Quedlinburg, Germany. September 7-10, 2008. Book of Abstracts. 155 pp.

Sárosi, Sz., Ruff, J. 2013. Optimization of solid phase microextraction conditions for analysis of garden thyme volatile compounds. Kertgazdaság 45: 7582 .

Salgueiro L. R., Proenca da Cunha P., Tomas, X., Canigueral, S., Adzet, T. and Vila, R. 1997. The essential oil of Thymus villosus L. ssp. villosus and its chemical polymorphism. Flavour and Fragrance Journal, 12:117-122.

Santos-Gomes, P. C. and Fernandes-Ferreira, M. 2001. Organ-and season-dependent variation in the essential oil composition of Salvia officinalis L. cultivated at two different sites. Journal of Agricultural and Food Chemistry 47: 2908-2916. doi: 10.1021/jf001102b

Schaunberg P. and Paris, F. 1977. Guida de las plantas medicinales. Barcelona: Omega, p. 316-317.

Simándi, B. and Sawinsky J. 1996. Műveletek szuperkritikus oldószerekkel. Olaj Szappan Kozmetika 45, Special issue: 3-11.

Stahl-Biskup E. 1991. The chemical composition of Thymus oils: A review of the Literature 1960-1989. Journal of Essential Oil Research 3:61-82. doi: 10.1080/10412905.1991.9697915

Stahl-Biskup, E. 2002. Essential oil chemistry of the genus Thymus -a global view. In: Thyme. The Genus Thymus. Stahl-Biskup, E., Sáez, F. Eds. Taylor Francis. London - New York. p. 45-124.

Sunar, S., Aksakal, O., Yildrim, N., Guleray, A., Gulluce, M., Sahin, F. 2009. Genetic diversity and relationship detected by FAME and RAPD analysis among Thymus species growing in eastern Anatolia region of Turkey. Romanian Biotechnological Letter 14: 4313-4318.

Szczepanik, M., Zawitowska B. and Szumny A. 2012. Insecticidal activities of Thymus vulgaris essential oil and its components (tyhmol and carvacrol) against larvae of lesser mealworm, Alphitobius diaperinus Panzer (Coleoptera: Tenebrionidae). Allelopathy Journal 30: 129-142. doi: 0971-4693/94

Ternes, W., Gronemeyer M. and Schwarz K. 1995. Determination of p-cymene-2,3-diol, thymol and carvacrol in different foodstuffs. Zeitschrift für Lebensmittel Untersuchung und Forschung 201: 544-577. doi: 10.1007/BF01201581

Thompson, J. D. 2002. Population structure and spatial dynamics of genetic plymorphism in thyme. In: Thyme. The Genus Thymus. Stahl-Biskup, E., Sáez, F. Eds. Taylor Francis. London - New York. p. 4448.

Trindade, H., Costa, M. M., Lima, A. S., Pedro, L. G., Figueiredo, A. C., Barroso, J. G. 2005. Chemical polymorphism and genetic diversity of Thymus caespititius: is there a correlation? $38^{\text {th }}$ International Symposium on Essential Oils. Graz, Austria. September 9-12, 2007. Book of Abstracts, p. 66.

Tung, Y. T., Chua, M. T., Wang S. Y. and Chang S. T. 2008. Anti-inflammation activities of essential oil and its constituents from indigenous cinnamon (Cinnamomum osmophloeum) twigs. Bioresource Tecnology 99: 3908-3913. doi:10.1016/j.biortech.2007.07.050

Usai, M., Marchetti M., Foddai M., Del Caro A., Desogus R. Sanna I. and Piga A. 2011. Influence of different stabilizing operations and storage time on the composition of essential oil of thyme (Thymus officinalis L.) and rosemary (Rosmarinus officinalis L.). LWT-Food Science and Technology 44: 244-249. doi:10.1016/j.lwt.2010.05.024

Vági, E., Simándi, B., Suhajda, Á. and Janzsó B. 2002. Microbiological activity of herb and spice extracts obtained by supercritical carbon dioxide extraction. Olaj, Szappan, Kozmetika 55 (Special issue): $48-51$.

Venskutonis, P. R. 1997. Effect of drying on the volatile constituents of thyme (Thymus vulgaris L.) and sage (Salvia officinalis L.). Food Chemistry 59: 219227. doi:10.1016/S0308-8146(96)00242-7

Venskutonis, P. R. 2002 Thyme - processing of raw plant material. In: Thyme. The Genus Thymus. StahlBiskup, E., Sáez, F. Eds. Taylor Francis. London New York. p. 224-234.

Vernet, P., Gouyon, P. H. and Valdeyron, G. 1986. Genetic control of the oil content in Thymus vulgaris L.: a case of polymorphism in a biosynthetic chain. Genetica 69: 227-231. doi: 10.1007/BF00133526

Vila, R. 2002. Flavonoids and further poliphenols in the genus Thymus. In: Thyme. The genus Thymus. Stahl-Biskup, E.-Sáez, F. Eds. Taylor Francis. London - New York. p. 144-176.

Yanishlieva, N. V., Marinova E. M., Gordon M. H. and Raneva V. G. 1999. Antioxidant activity and mechanism of action of thymol and carvacrol in two lipid systems. Food Chemistry 50: 5480-5484. doi:10.1016/S0308-8146(98)00086-7

Zambonelli, A., Zechini D’Aulerio A., Bianchi A. and Albasini A. 1996. Effects of essential oil on phytopathogenic fungi in vitro. Journal of Phytopathology 144: 491-494. doi: 10.1111/j.14390434.1996.tb00330.x

Zarzuelo A and Crespo, E. 2002. The medicinal and nonmedicinal uses of thyme. In: Stahl-Biskup E., Sáez F. (Eds.): Thyme. The genus Thymus. London and New York, Taylor \& Francis, p. 263-292. 